\title{
ASSESSMENT OF FACTOR INFLUENCING ATTRACTION OF FOREIGN DIRECT INVESTMENT TO DEVELOPING ECONOMIES
}

\author{
Konstantin Igorevich KOZHEVNIKOV \\ Department of Price Formation in Construction and Industry \\ Ural Federal University named after the first President of \\ Russia B.N. Yeltsin \\ Yekaterinburg, Russian Federation
}

\author{
Oleg Victorovich BAZHENOV \\ Department of Accounting, Analysis and Audit \\ Ural Federal University named after the first President of \\ Russia B.N. Yeltsin \\ Yekaterinburg, Russian Federation \\ o.v.bazhenov@urfu.ru
}

Stanislav Victorovich PRIDVIZHKIN

Department of Price Formation in Construction and Industry Ural Federal University named after the first President of Russia B.N. Yeltsin

Yekaterinburg, Russian Federation

\section{Margarita Karpovna KOZHEVNIKOVA}

Department of Price Formation in Construction and Industry Ural Federal University named after the first President of Russia B.N. Yeltsin

Yekaterinburg, Russian Federation

\section{Yelizaveta Aleksandrovna ZASUKHINA AO PF SKB KONTUR \\ Yekaterinburg, Russian Federation}

\begin{abstract}
Modern trends in economic development are characterized by intensification of competition, globalization of markets and concentration of capital. Attracting foreign direct investment plays a significant role in the growth of developing economies. Assessment of influence that the foreign capital exerts on the receiving party was studied in-depth by a wide range of Russian and foreign scholars, however, the issue is still a debating point among the modern economists. Due to this, the purpose of this paper is to reveal and evaluate the factors that influence attraction of foreign direct investment to developing economies. The paper uses comparative analysis and generalization of available information as its main methods; besides that, it undertakes a content analysis of reports and analytical pieces from leading Russian and foreign works published during several recent decades pertaining to the issue of determination of factors influencing the size of direct foreign investment. An econometric model was conceived from the statistical data covering 19 developing economies that allows estimation of influence from different factors onto the net inflows of direct foreign investments. Dwelling on existing economic theories that describe the economic nature of direct foreign investments, two groups of influence factors were discovered, namely: a group of macroeconomic factors and a group of factors linked to general societal development (11 factors in total). In conclusion, the authors reflect upon the degree and the direction of influence that the macroeconomic and societal development factors have on the net amount of direct foreign investment.
\end{abstract}

Keywords-direct foreign investment; developing economies; investment attractiveness, econometric model; factor analysis; international economy.

\section{INTRODUCTION}

According to provisions of regulations of the International Monetary Fund (IMF), the international investments may be divided into three groups: portfolio, direct and others.

At that, foreign direct investment (FDI) is usually defined as ownership of assets of one country (or several countries) on behalf of residents of a different country with the aim of controlling the use of such assets. Acquiring a share of charter capital of $10 \%$ or more is considered a direct investment [1].

Factors, influencing attraction of the direct foreign investments to developing economies, were studied in works of leading Russian and foreign economists, but there is still no common universal model with factors that can unambiguously explain attraction of the FDI.

An overview and brief characteristics of several modern scholars' opinions on factors influencing the FDI are given in Table 1.Ease of Use

In their work, the authors study the factors that influence attraction of the foreign direct investment to a number of developing economies: Argentina, Brazil, China, Chile, India, Indonesia, Malaysia, Paraguay, Peru, Russia, the Republic of South Africa, South Korea, Uruguay, Venezuela, Kazakhstan, Vietnam, the Philippines, Thailand. 
FACTORS INFLUENCING THE DIRECT FOREIGN INVESTMENT. OVERVIEW OF MODERN SCHOLARS' OPINIONS

\begin{tabular}{|c|c|c|c|}
\hline Work title & Authors & Year & Variables. Direction of influence $(+,-)$ \\
\hline $\begin{array}{l}\text { «Determinants of foreign direct investment in } \\
\text { BRICS economies: Analysis of economic, } \\
\text { institutional and political factor» }\end{array}$ & Pravin Jadhav & 2012 & $\begin{array}{l}\text { openness }+\quad \text { market volume }+ \\
\text { inflation }+ \text { institutional and political group of } \\
\text { data are mainly insignificant }\end{array}$ \\
\hline $\begin{array}{l}\text { «Better the devil you don't know: Types of } \\
\text { corruption and FDI in transition economies» }\end{array}$ & Alvaro Cuervo-Cazurras & 2006 & $\begin{array}{l}\text { corruption level and low legal transparency are } \\
\text { statistically significant and have negative } \\
\text { influence on investrors' decision }\end{array}$ \\
\hline $\begin{array}{l}\text { «Foreign direct investment and its } \\
\text { determinants: A regional panel causality } \\
\text { analysis» }\end{array}$ & $\begin{array}{l}\text { M.W. Luke Chana,b, } \\
\text { Keqiang Houb, Xing Lic, } \\
\text { Dean C. Mountain }\end{array}$ & 2013 & $\begin{array}{l}\text { Gross Regional Product }+ \text {, wages -, education }+ \text {, } \\
\text { cellular network coverage }+,(90 \%) \text { roads }+\end{array}$ \\
\hline $\begin{array}{l}\text { «Human Capital and FDI Inflow: An } \\
\text { Assessment of the African Case» }\end{array}$ & $\begin{array}{l}\text { Emmanuel A. Cleeve, Yaw } \\
\text { Debrah, Zelealem Yiheyis }\end{array}$ & 2015 & GDP growth + , inflation,+ HDI + \\
\hline $\begin{array}{l}\text { «Robust FDI determinants: Bayesian Model } \\
\text { Averaging in the presence of selection bias» }\end{array}$ & $\begin{array}{l}\text { Theo S. Eicher, Lindy } \\
\text { Helfman, Alex Lenkoski }\end{array}$ & 2012 & Education level \\
\hline $\begin{array}{l}\text { «Determinants of Foreign Direct Investment } \\
\text { in Developing Countries: A Comparative } \\
\text { Analysis» }\end{array}$ & $\begin{array}{l}\text { Khondoker Abdul } \\
\text { Mottaleba, Kaliappa } \\
\text { Kalirajanb }\end{array}$ & 2011 & $\begin{array}{l}\text { Size }+ \text {, GDP growth }+, \\
\text { openness }+ \text {, expenses -, wages -, inflation } \\
+,\end{array}$ \\
\hline $\begin{array}{l}\text { «Do changes in the rules of the game affect } \\
\text { FDI flows in Latin America? A look at the } \\
\text { macroeconomic, institutional and regional } \\
\text { integration determinants of FDI» }\end{array}$ & $\begin{array}{l}\text { Miguel Eduardo Sánchez- } \\
\text { Martín, Rafael de Arce, } \\
\text { Gonzalo Escribano }\end{array}$ & 2014 & $\begin{array}{l}\text { openness }+, \text { short-term loans support }+ \\
\text { government st }+ \text { low expropriation risks }+\end{array}$ \\
\hline $\begin{array}{l}\text { Determinants of Foreign Direct Investment in } \\
\text { China: A Sectoral Analysis }\end{array}$ & Owen C.H. Ho & 2014 & $\begin{array}{l}\text { market size }+, \text { wages level }-, \text { domestic investment } \\
+, \quad \text { innovations }+\end{array}$ \\
\hline
\end{tabular}

TABLE II.

POTENTIAL VARIABLES ${ }^{2}$

\begin{tabular}{|c|c|c|}
\hline Group & Code of variable & Comment \\
\hline \multirow{7}{*}{ Macroeconomic } & GDP1 & GDP. In billions of USD. \\
\hline & GDP2 & GDP per capita. In billions of USD. \\
\hline & GDP3 & $\%$ GDP growth \\
\hline & POP & Population. In millions of people. \\
\hline & NEX & Net export. In billions of USD. \\
\hline & INFL & Inflation $(\%)$ \\
\hline & OPENNESS & Trade to GDP ratio $(\%)$ \\
\hline \multirow{4}{*}{$\begin{array}{c}\text { Societal } \\
\text { Development }\end{array}$} & $\mathrm{RD}$ & $\mathrm{R} \& \mathrm{D}$ costs as percentage of GDP $(\%)$ \\
\hline & HDI & Human Development Index \\
\hline & IU & Internet users per 100 people \\
\hline & EDU & Tertiary education degree holders (per 100,000 population) \\
\hline
\end{tabular}

${ }^{1}$ The table is compiled by the authors from [2-10]

${ }^{2}$ The table is compiled by the authors from [2-10] 
At that, net inflow of the foreign direct investment (FDI) serves as a referable variable. The explaining variables may be divided into two groups: macroeconomic variables and the variables that reflect the societal development. Table 2 shows several hypotheses on significance of 14 potential regressors selected from the literature review.

\section{RESEARCH METHODOLOGY.}

To determine the factors, their direction and degree of influence onto the net inflow of foreign direct investment, the paper considers panel data from the 19 countries listed above for a period from 2000 to 2015 .
Let us consider the model with all the variables, potentially influencing the net inflow of the FDI.

Formula: FDI $\sim \log ($ GDP2 $)+\log ($ POP $)+$ NEX + INFL + OPENNESS + RD $+\log ($ HDI $)+\log ($ IU $)+\log ($ EDU $)+$ DR + DUMMY

The econometric calculations were performed in $\mathrm{R}$ statistical software package. The dummy variable was removed by the software due to its being a constant. The results are given in Table 3.

TABLE III. RESULTS OF POTENTIAL REGRESSORS EVALUATION3

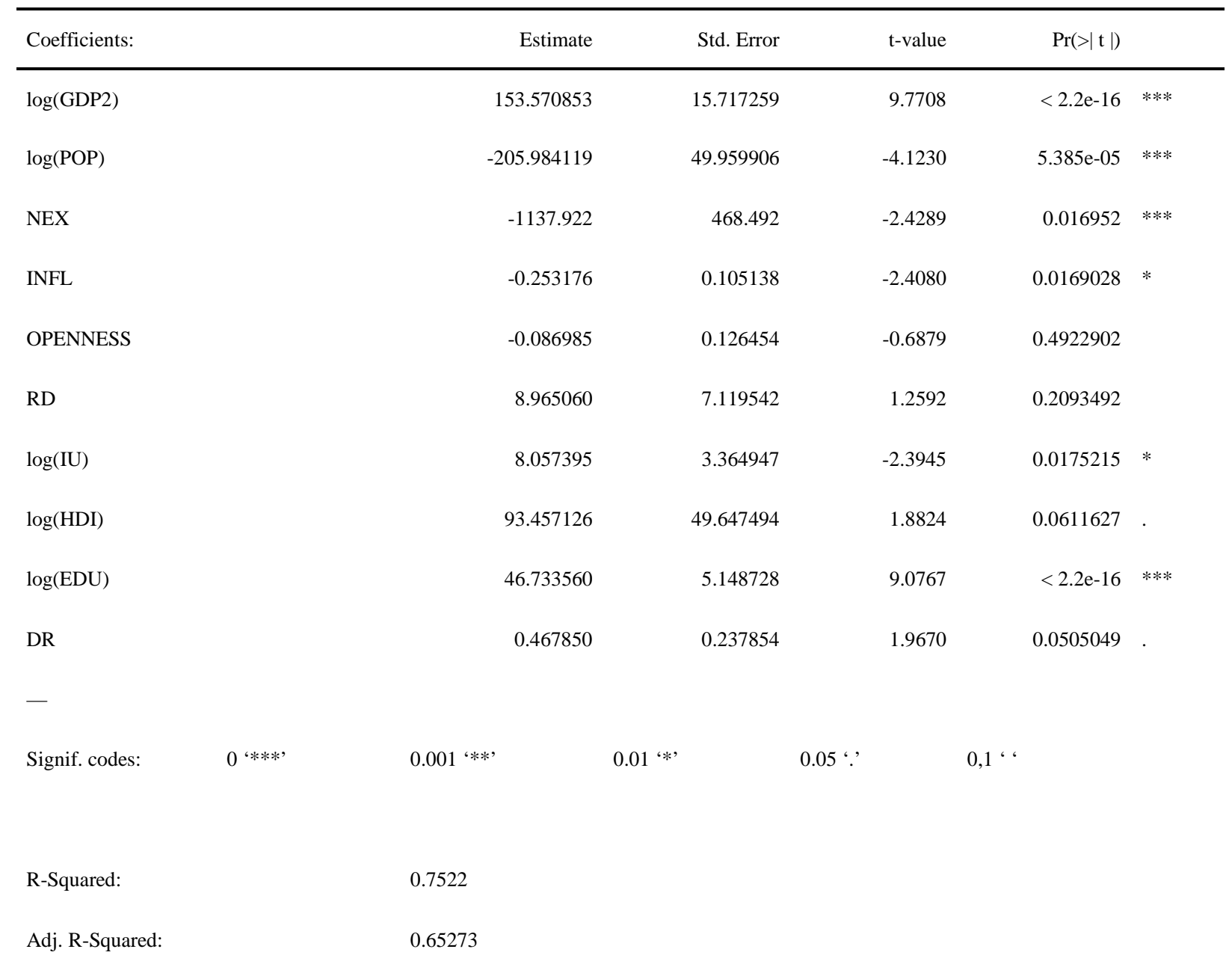

\footnotetext{
${ }^{3}$ The table created by the authors with the help of R statistical software package

$* * *$ - the variable has significance at a $1 \%$ level

** - the variable has significance at a $5 \%$ level

* - the variable has significance at a $10 \%$ level
} 
After the logarithmizing, a Breusch-Pagan test was conducted to check for heteroscedasticity of regression model random errors.

The model becomes represented by the following equation:

$\begin{array}{cl}\mathrm{FDI}=14.494576 * \log (\mathrm{GDP} 2) & +0.346378 * \mathrm{NEX}+ \\ 0.210686 * \mathrm{INFL}+ & 11.352373 * \log (\mathrm{IU}) \\ 163.886077 * \log (\mathrm{HDI})+42.177576 * \log (\mathrm{EDU}) & +\end{array}$

Inflation is statistically significant. However, a hypothesis of negative influence of inflation onto the FDI was rejected. It may be explained by the fact that in developing economies, an active economic growth is accompanied by high inflation. So, in a manner, inflation may be a characteristic of a growing economy.

The authors' sample consists of developing economies, which are not isolated from the rest of the world. There are certain macroeconomic effects that change through time and are partially created by the external world. In particular, this sample range covers the crisis year, which is a supposition for evaluation of two-way fixed effects, where not only individual, but temporal effects are assessed as well.

The model becomes represented by the following equation:

$$
\begin{aligned}
& \text { FDI }=13.973772 * \log (\mathrm{GDP} 2)+0.367072 * \mathrm{NEX}+ \\
& 0.287902 * \mathrm{INFL}+ \\
& 113.947873 * \log (\mathrm{HDI})+46.372233 * \log (\mathrm{EDU})
\end{aligned}
$$

Next a genetic algorithm is applied to select regressors [11]. As a result, the authors can conclude on practicability to apply a data sampling in a logarithmic form. The variable POP is excluded from the model to avoid a multicollinearity problem.

$$
\underset{\log (\mathrm{EDU})}{\mathrm{FDI} \sim \log (\mathrm{GDP} 2)}+\mathrm{NEX}+\mathrm{INFL}+\log (\mathrm{HDI})+\log (\mathrm{IU})+
$$

Let us assess the model with the least square method [12].

Due to non-uniformity of data, to obtain a linear model, let us use a semilogarithmic model. It was decided not to logarithmize the values of FDI and NEX due to the presence of negative values. The same was decided about the value of INF, because it is already measured in percentages and additional logarithmizing my reduce the factor's estimation.

Next a genetic algorithm is applied to select regressors [11]. As a result, the authors can conclude on practicability to apply a data sampling in a logarithmic form. The variable POP is excluded from the model to avoid a multicollinearity problem.

$$
\underset{\log (\mathrm{EDU})}{\mathrm{FDI} \sim \log (\mathrm{GDP} 2)}+\mathrm{NEX}+\mathrm{INFL}+\log (\mathrm{HDI})+\log (\mathrm{IU})+
$$

Let us assess the model with the least square method [12].

Due to non-uniformity of data, to obtain a linear model, let us use a semilogarithmic model. It was decided not to logarithmize the values of FDI and NEX due to the presence of negative values. The same was decided about the value of
INF, because it is already measured in percentages and additional logarithmizing my reduce the factor's estimation.

After the logarithmizing, a Breusch-Pagan test was conducted to check for heteroscedasticity of regression model random errors.

The model becomes represented by the following equation:

$$
\begin{array}{cc}
\mathrm{FDI}=14.494576 * \log (\mathrm{GDP} 2)+0.346378 * \mathrm{NEX}+ \\
0.210686 * \mathrm{INFL}+ \\
163.886077 * \log (\mathrm{HDI})+42.177576 * \log (\mathrm{EDU})
\end{array}
$$

Inflation is statistically significant. However, a hypothesis of negative influence of inflation onto the FDI was rejected. It may be explained by the fact that in developing economies, an active economic growth is accompanied by high inflation. So, in a manner, inflation may be a characteristic of a growing economy.

The authors' sample consists of developing economies, which are not isolated from the rest of the world. There are certain macroeconomic effects that change through time and are partially created by the external world. In particular, this sample range covers the crisis year, which is a supposition for evaluation of two-way fixed effects, where not only individual, but temporal effects are assessed as well.

The model becomes represented by the following equation:

$\mathrm{FDI}=13.973772 * \log (\mathrm{GDP} 2)+0.367072 * \mathrm{NEX}+$
$0.287902 * \mathrm{INFL}+\quad(5) \quad 10.831854 * \log (\mathrm{IU})+$
$113.947873 * \log (\mathrm{HDI})+46.372233 * \log (\mathrm{EDU})$

\section{RESULTS AND DISCUSSION.}

When GDP per capita grows by $1 \%$, inflow of FDI increases by 0.13 billion dollars. The positive influence of GDP per capita supports the hypothesis that investments are primarily aimed at bigger and richer countries so that to get the economy of scale.

An increase in net export by 1 billion dollars brings in additional 0.367072 billion dollars of FDI.

An increase in inflation by $1 \%$ brings in additional 0.287902 billion dollars of FDI.

Additional $1 \%$ of Internet users brings in additional 0.1 billion dollars in FDI.

An increase in HDI by $1 \%$ brings in additional 1.13 billion dollars of FDI.

Additional $1 \%$ of tertiary education graduates brings in additional 0.46 billion dollars in FDI.

The regression as a whole is significant, so it is reasonable to assess temporal effects alongside with the individual effects. Due to the presence of the crisis year in the data, it was decided to perform a Chow test for structural break. The test has shown that there are structural breaks in the data and it is more practical to divide the sample into two parts: pre-crisis and post-crisis periods. 
In this case, the sample is divided into pre-crisis and postcrisis parts and the model (3) is tested in different periods.

The obtained results allow for conclusion that the model (3) is inefficient in explaining the FDI attraction in the period following 2008. This may be explained by the caution that investors show due to the world crisis. A proposal was made that FDI attraction after 2008 is largely explained by the FDI value of a previous period. In other words, the investors look to their previous experience.

To explain FDI attraction to the developing economies following 2008, the authors proposed a hypothesis that there would be a decline in growth rate of investment inflow and that the investors are going to look to previous experience, that is, FDI values of the previous year are going to influence values of this year [13]. Let us consider the first differences, that is, FDI per capita and GDP per capita with a lag of 1. As FDI regresses onto itself, the model is dynamic. A method of moments and Arrelano-Bond estimator are used for evaluation of the model.

The specification includes the complete history of regressors as the dependent variable; a problem or correlation between this variable and a random number arises. ArrelanoBond estimator [14] allows for resolving those problems. The procedure is based upon application of the generalized method of moments to search the values of the initial model coefficients with transformation to the first differences. In this case, individual coefficients cannot be assessed, but the whole estimation becomes more efficient. Besides that, the use of Arrelano-Bond estimator is recommended for cases with a low number of temporal periods available for considerations, which is one of the characteristics of the data.

The final model becomes represented by the following equation:

FDI $=0.18306885+59.81540054 \operatorname{lag}(\mathrm{FDI}, \quad 1)+$ $0.00718713 \operatorname{lag}(\log G D P 2,1)$

The results show that the model is significant as a whole, all the factors are significant with the exception of GDP per capita in the current period. Arguably, during the crisis period, more investment are drawn to countries where a high level of inflowing investment and high GDP per capita have been seen up to the crisis.

Thus, the theories that give significance to low inflation (Pravin Jadhav, 2012), growth of net export, infrastructural development (M.W. Luke Chana,b, Keqiang Houb, Xing Lic, Dean C. Mountain, 2013) and HDI (Emmanuel A. Cleeve, Yaw Debrah, Zelealem Yiheyis, 2015) in the post-crisis period in developing economies were rejected. The theory that gives significance to economic development (Owen C.H. Ho, 2011) was supported by the research.

\section{CONCLUSION}

Thus, this paper showed an evaluation of factors influencing attraction of foreign direct investment to developing economies. Due to the fact that the model (3) allows for explanations of investment attraction to a country during a non-crisis period, one may conclude that stable growth, accumulation of human capital and infrastructural development are especially important [15].

Dwelling on the UNCTAD report, the authors conclude that there are three trends in direct investments: oil and gas (especially shale oil), pharmaceuticals, retail.

For all the countries which were considered in this paper, the principal economic sector accumulating the direct investments is retail. Argentina and China have rich reserves of shale oil [16]. India sees transactions in pharmaceutical industry. However, as evident from the Figure, presently the most part of the transactions in this field happens in developed economies, which are the source of the investments. Both shale oil production and pharmaceuticals are high-tech industries. Thus, it is important for economies to accumulate human capital [17].

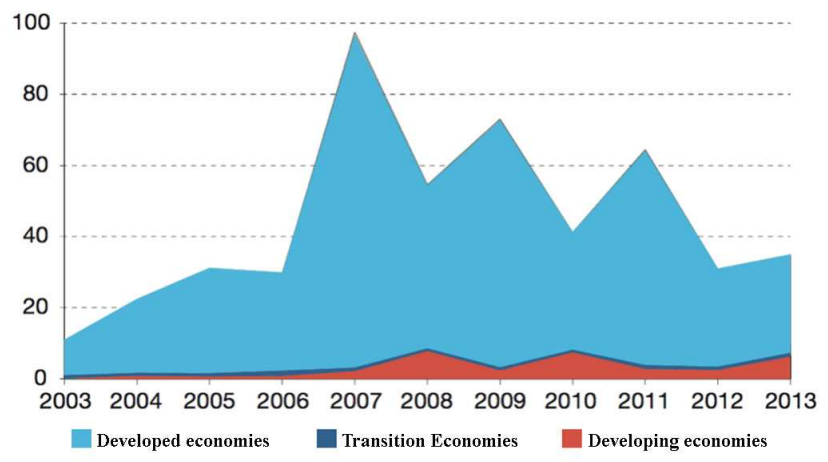

Fig. 1. Trans-border M\&A transactions in pharmaceuticals (billion \$)

Thus, in a situation where raw material prices are relatively low, it is necessary to develop infrastructure, provide a high level of education, provide a relatively high level of consumption and trade. All these factors will allow attracting foreign investments, thus creating a more competitive environment and, as a result, a high-tech manufacturing.

\section{References}

[1] G.M. Kostyunina, International Movement of Capital, Moscow: TK Velbi, Prospect, 2005, 351 p.

[2] Alvaro Cuervo-Cazurras, Better the devil you don't know: Types of corruption and FDI in transition economies, Journal of International Management, 14, pp. 12-27, 2008.

[3] Emmanuel A. Cleeve, Yaw Debrah, Zelealem Yiheyis. Human Capital and FDI Inflow: An Assessment of the African Case, World Development, Vol. 74, pp. 1-14, 2015.

[4] 4. Foreign Direct Investment in Developing Countries: A Comparative Analysis, ASARC Working Paper, 2011.

[5] M.W. Luke Chana, Keqiang Houb, Xing Lic, Dean C. Mountain. Foreign direct investment and its determinants: A regional panel causality analysis, The Quarterly Review of Economics and Finance 54, pp. 579-589, 2014.

[6] C.H. Owen, Ho. Determinants of Foreign Direct Investment in China: A Sectoral Analysis, School of Economics \& Commerce University of Western Australia, 2011.

[7] Pravin Jadhav. Determinants of foreign direct investment in BRICS economies: Analysis of economic, institutional and political factor, Social and Behavioral Sciences, 37, pp. 5-14, 2012. 
[8] Sayek, FDI in Turkey: the investment climate and EU effects, J. Int. Trade Dipl, 2007.

[9] Shiva S. Makki. Impact of Foreign Direct Investment and Trade on Economic Growth. 2006.

[10] S. Theo Eicher, Lindy Helfman, Alex Lenkoski, Robust FDI determinants: Bayesian Model Averaging in the presence of selection bias, Journal of Macroeconomics, 34, pp. 637-651,2012.

[11] Ivan Savin, Andrey Pushkarev. Monte Carlo Methods in Economic, UrFU, pp. 41-42, 2015.

[12] I.M. Drapkin, O.C. Mariyev, K.V. Chukavina, A Quantitative Evaluation of Import And Export Potential of the Foreign Direct Investment in the Russian Economy with a Gravity Approach, Journal of New Economic Association, № 4, pp. 75-95, 2015.

[13] Grossman and Helpman. Outsourcing versus FDI in industry equilibrium, Eur. Econ. Assoc, 1 (2-3), pp. 317-327 (MIT Press), 2004.
[14] Manuel Arellano and Stephen Bond. Some Tests of Specification for Panel Data: Monte Carlo Evidence and an Application to Employment Equations, The Review of Economic Studies, Vol. 58, no. 2, pp. $277-$ 297, Apr., 1991.

[15] Te Velde and Bezemer. Regional integration and foreign direct investment in developing countries, Rev. World Econ, 143 (2), pp. 277 305, 2006.

[16] Miguel Eduardo Sánchez-Martín, Rafael de Arce, Gonzalo Escribano. Do changes in the rules of the game affect FDI flows in Latin America? A look at the macroeconomic, institutional and regional integration determinants of FDI, European Journal of Political Economy 34, pp. 279-299, 2014.

[17] Rodrik, A. Subramanian, F. Trebbi, Institutions rule: the primacy of institutions over geography and integration in economic development, J. Econ. Growth, 9 (2), pp. 131-165, 2004. 